\title{
Requirements for Fertility Preservation for Cancer Patients and Healthy Individuals
}

\author{
Murid Javed* and Hamad Al Sufyan \\ Thuriah Medical Center, ART Laboratory, Saudi Arabia \\ *Corresponding author: Murid Javed, Thuriah Medical Center, ART Laboratory, Saudi Arabia
}

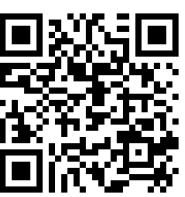

\begin{tabular}{|c|c|}
\hline ARTICLE INFO & ABSTRACT \\
\hline Received: 栔August 07, 2019 & Citation: Murid Javed, Hamad Al Sufyan. Requirements for Fertility Preservation for \\
\hline Published: 豐 August 13, 2019 & $\begin{array}{l}\text { Cancer Patients and Healthy Individuals. Biomed J Sci \& Tech Res 20(3)-2019. BJSTR. } \\
\text { MS.ID.003464. }\end{array}$ \\
\hline
\end{tabular}

\section{Opinion}

Advances in cancer awareness, early detection, diagnosis and treatment have increased survival of male and female cancer patients [1,2]. A multidisciplinary team is involved in treatment of cancer patient. The major goal of this team is to save life. However, cancer treatment may cause infertility in both males and females, thus fertility preservation is essential [3,4]. Significant advances have been made in fertility preservation of pre-pubertal, pubertal and adult patients $[5,6]$. Since fertility preservation facilities are not directly involved in treatment of cancer patients, their role is either inadvertently missed or patient is given a very short time for fertility preservation. Sperm, testicular tissue, oocyte, and embryo cryopreservation is done for other reasons as well [7-9]. Usually the cancer patients, healthy individuals or referring physicians are not aware of the requirements by the fertility preservation facilities which increases stress and results in delay of cryopreservation. The purpose of this opinion is to enhance awareness about requirements of the fertility preservation and to emphasize timely communication between cancer patient or healthy individual and the fertility preservation facility to reduce stress and properly safeguard future fertility. Fertility preservation, sperm cryopreservation, testicular tissue, ovarian tissue, oocyte cryopreservation

\section{General Requirements of Fertility Preservation for Male and Female}

Following are general requirements that may vary among different fertility preservation facilities.

Cryopreservation Consent and Storage Contract: The cancer patient or the healthy individual has to be physically present to sign the cryopreservation consent and storage contract. It is very important to mention future disposition of the stored samples.
Usual options include; for use by cancer patient's/healthy individual's spouse, disposition for research or disposal if the cryopreserved samples are no longer needed or in the event of no survival of cancer patient or individual's death. The storage contract is usually for one year and has to be renewed every year, however, with mutual agreement and payment of dues, the contract can be extended. However, in some situations, there may be statutory time limit for storage of gametes [10]. The responsibility of agreement renewal and updating contacts (if they change) is responsibility of patient or individual. The fertility preservation facility can't afford to keep the unpaid samples for unlimited time therefore, the samples may be disposed if contract is not renewed. Technically, the samples can be stored in liquid nitrogen for a long time provided the liquid nitrogen level is maintained regularly [11,12]. Most of the damage to the sample happens at cryopreservation or warming. With the advent of vitrification, post- warming survival of eggs and embryos is reaching high limits [13]. Sperm and testicular tissue cryopreservation have been in practice for several years and are very successful procedures [14].

\section{Results of Communicable Disease Tests}

The viruses and bacteria survive in ultra- low temperature of liquid nitrogen and there is a possibility of cross contamination of samples during storage $[15,16]$. Thus, cancer patient or individual is asked to provide results of at least Hepatitis B, Hepatitis C, HIV and HTLV testing. Usually the cancer patients are tested for these communicable infections. It will save their time and reduce stress if copy of these results is provided to the fertility preservation facility. This infection testing requirement may vary among different facilities. If any cancer patient/individual reacts positive to any of the above viral infection, the samples can be stored in a container 
where other stored samples have shown positive reaction. Usually the fertility preservation facilities have 2 types of storage; for negative and for positive reacting samples. Alternatively, either the cancer patient or the fertility preservation facility may arrange a small vapor shipper to store samples isolated from the clean storage.

\section{Number of Samples to be Cryopreserved}

The number of samples to be cryopreserved depends on number of children desired, type and quality of the sample. Fertility counselor and the fertility preservation facility can provide some guidance, but the final decision is to be made by the cancer patient or the healthy individual.

\section{Options for Male}

a) The male capable of producing semen, usually $48 \mathrm{~h}$ abstinence is recommended in between 2 ejaculates. Shorter abstinence [17] or collection of 2 samples on the same day is suggested if limited time is available. If the sperm number and motility meet WHO normal sample parameters [18], samples can be preserved for IUI, otherwise, sperm can be frozen for ICSI procedure. b) In pre-pubertal boys suffering from cancer and men incapable of ejaculation, Testicular Sperm Aspiration (TESA), Percutaneous Sperm Aspiration (PESA), MicroSurgical Epididymal Sperm Aspiration (MESA) or MicroSurgical Testicular Sperm Extraction (Micro-TESE) can be attempted [19]. These procedures involve a fertility surgeon and anesthesiologist in addition to fertility preservation laboratory, therefore, appointment should be booked as soon as possible. Testicular tissue cryopreservation is successful, and many births have been achieved utilizing sperm retrieved from frozen-thawed testicular tissue [20]. Figure 1 explains male reproductive system and different sources of sperm for cryopreservation.

\section{Options for Female}

a) Oocyte cryopreservation is now commonly applied procedure [9]. It is the only option for unmarried females. Oocytes can be collected trans-abdominally [21] instead of trans-vaginally. The success rate depends on age of patient and quality and maturity of oocytes. The oocytes can be collected twice during one menstrual period [22]. The number of oocytes to be frozen depends on age, ovarian reserve, future plans and quality of sperm to be used.

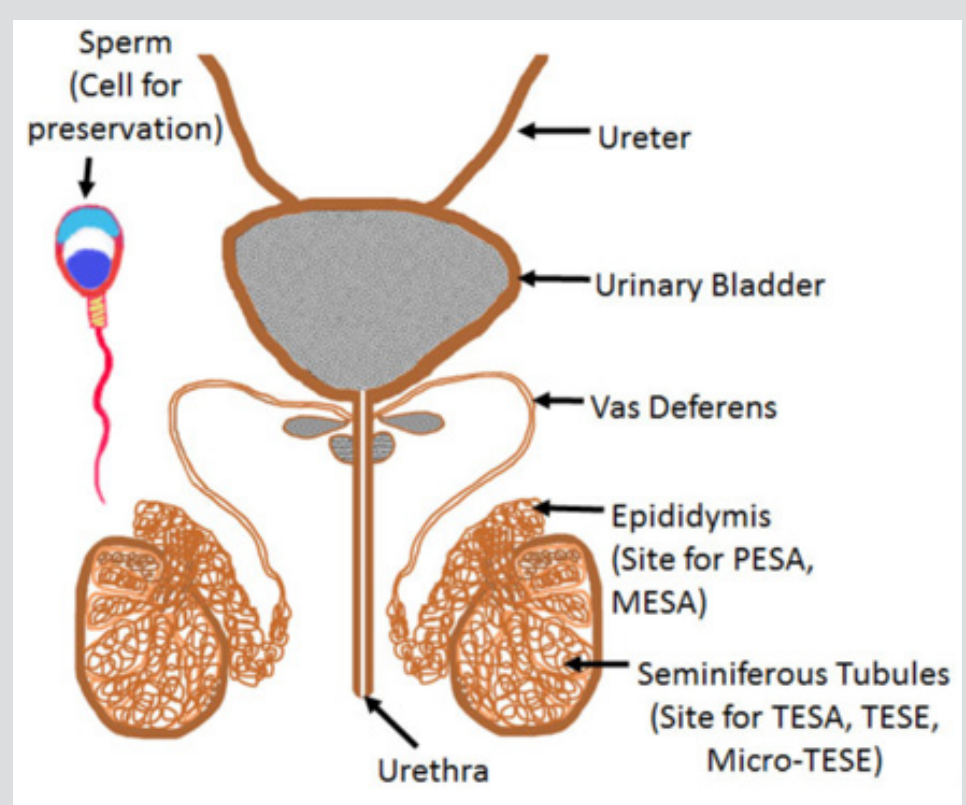

Figure 1: In male, the cell to be cryopreserved is "sperm" which can be obtained from ejaculate, from epididymis or the seminiferous tubules in testes.

b) Embryo freezing is an option for married females. Very high embryo survival rate [13] and high pregnancy rate [23] can be expected depending on age of female. The embryos can be frozen on day 3 or day 5 depending on choice of the individual, reproductive endocrinologist and the fertility preservation laboratory. c) For female cancer patients, ovarian tissue cryopreservation has been done successfully [24]. There is possibility of re-introduction of cancer on re-implantation of the tissue. In vitro follicular culture, in vitro oocyte maturation [25] and use of synthetic ovary are still experimental and not available clinically. Figure 2 shows female reproductive system explaining source of oocytes which has to be preserved to secure fertility. 


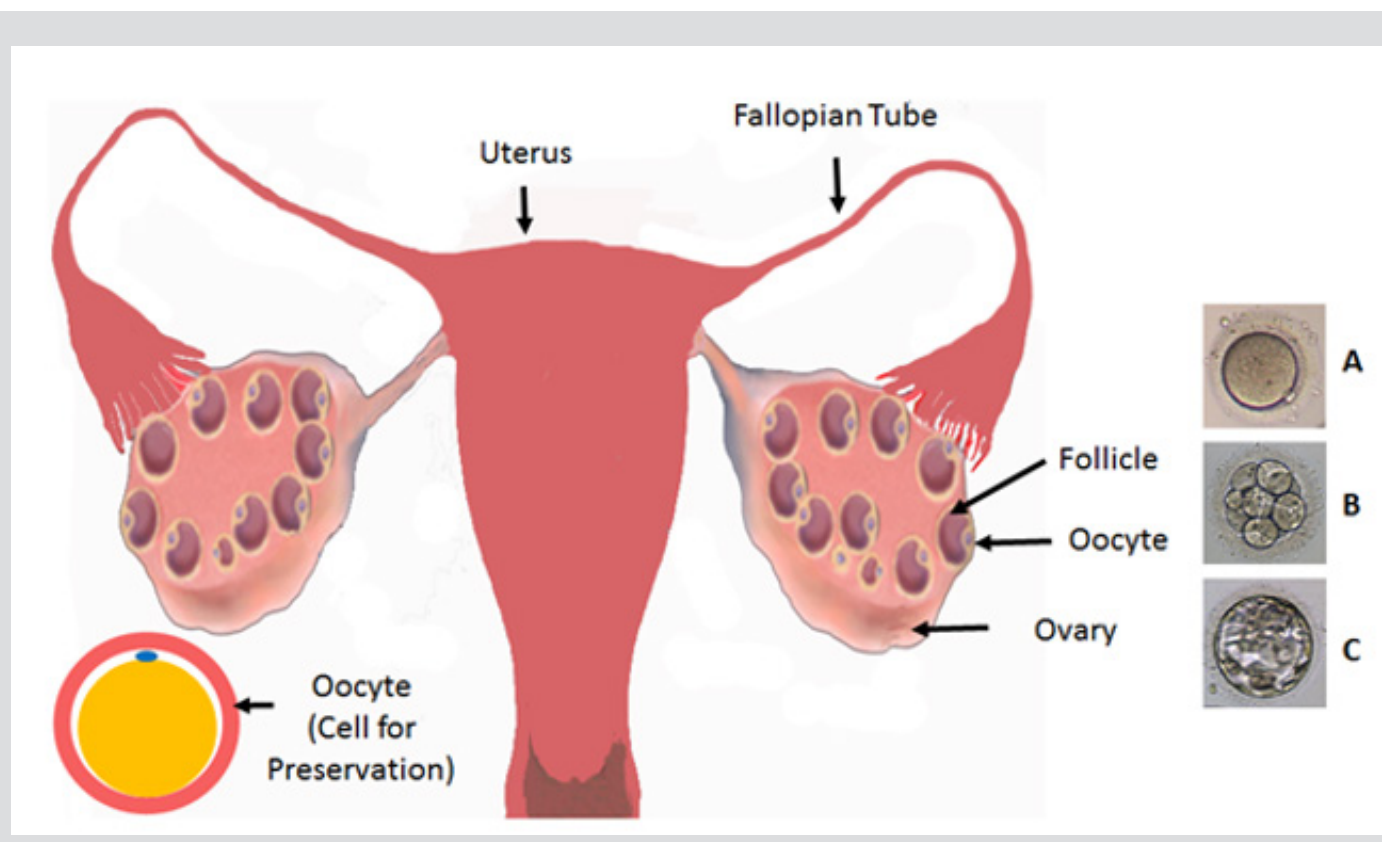

Figure 2: Female reproductive system showing source of oocytes in stimulated ovaries. On the right side, $A=$ mature oocyte, $\mathrm{B}=$ day -3 embryo and $\mathrm{C}=$ day -5 embryo.

\section{Conclusion}

Fertility preservation is becoming increasingly important not only for cancer and infertile patients but also for healthy individuals. Fertility preservation facilities may have different requirements and capabilities to preserve gametes, embryos and tissues. It is highly important to communicate in advance with the fertility preservation facility to reduce stress and delays in preservation. The gamete or tissue owner is recommended to direct the future use of their gametes or tissues.

\section{References}

1. Scher HI, Fizazi K, Saad F, Taplin ME, Sternberg CN, et al. (2012) Increased survival with enzalutamide in prostate cancer after chemotherapy. New England Journal of Medicine 367: 1187-1197.

2. Von Hoff DD, Ervin T, Arena FP, Chiorean EG, Infante J, et al. (2013) Increased survival in pancreatic cancer with nab-paclitaxel plus gemcitabine. New England Journal of Medicine 369(18): 1691-1703.

3. McLaren JF, Bates GW (2012) Fertility preservation in women of reproductive age with cancer. American journal of obstetrics and gynecology 207(6): 455-462.

4. Knopman JM, Papadopoulos EB, Grifo JA, Fino ME, Noyes N (2010) Surviving childhood and reproductive-age malignancy: effects on fertility and future parenthood. The lancet oncology 11(5): 490-498.

5. De Vos M, Smitz J, Woodruff TK (2014) Fertility preservation in women with cancer. The Lancet 384(9950): 1302-1310.

6. De Michele F, Poels J, Giudice MG, De Smedt F, Ambroise J, et al. (2018) In vitro formation of the blood-testis barrier during long-term organotypic culture of human prepubertal tissue: comparison with a large cohort of pre/peripubertal boys. MHR: Basic science of reproductive medicine 24(5): 271-282.

7. La Marca A, Dal Canto M, Buccheri M, Valerio M, Mignini RM, et al. (2019) A novel transnational fresh oocyte donation (TOD) program based on transport of frozen sperm and embryos. Hum Reprod 34(2): 285-290.
8. Valli-Pulaski H, Peters KA, Gassei K, Steimer SR, Sukhwani M, et al. (2019) Testicular tissue cryopreservation: 8 years of experience from a coordinated network of academic centers. Hum Reprod 34(6): 966-977.

9. Mintziori G, Veneti S, Kolibianakis EM, Grimbizis GF, Goulis DG (2019) Egg freezing and late motherhood. Maturitas 125: 1-4.

10. Jackson E (2016) 'Social' egg freezing and the UK's statutory storage time limits. J Med Ethics 42(11): 738-741.

11. Yogev L, Kleiman SE, Shabtai E, Botchan A, Paz G, Hauser R, et al. (2010) Long-term cryostorage of sperm in a human sperm bank does not damage progressive motility concentration. Hum Reprod 25(5): 10971103.

12. Huang C, Lei L, Wu HL, Gan RX, Yuan XB, et al. (2019) Long-term cryostorage of semen in a human sperm bank does not affect clinical outcomes. Fertil Steril.

13. Antinori M, Licata E, Dani G, Cerusico F, Versaci C, et al. (2007) Cryotop vitrification of human oocytes results in high survival rate and healthy deliveries. Reproductive BioMedicine Online 14(1): 72-79.

14. Keros V, Rosenlund B, Hultenby K, Aghajanova L, Levkov L, et al. (2005) Optimizing cryopreservation of human testicular tissue: comparison of protocols with glycerol, propanediol and dimethylsulphoxide as cryoprotectants. Hum Reprod 20(6): 1676-1687.

15. Bielanski A, Bergeron H, Lau PC, Devenish J (2003) Microbial contamination of embryos and semen during long term banking in liquid nitrogen. Cryobiology 46(2): 146-152.

16. Joaquim DC, Borges ED, Viana IGR, Navarro PA, Vireque AA (2017) Risk of Contamination of Gametes and Embryos during Cryopreservation and Measures to Prevent Cross-Contamination. Biomed Res Int. pp. 11.

17. Agarwal A, Sidhu RK, Shekarriz M, Thomas AJ (1995) Optimum abstinence time for cryopreservation of semen in cancer. J Urol. 154(1): 86-88.

18. (2010) World Health Organization: WHO laboratory manual for the examination and processing of human semen.

19. Agarwal A, Ong C, Durairajanayagam D (2014) Contemporary and future insights into fertility preservation in male cancer patients. Translational andrology and urology 3(1): 27-40. 
20. Wu B1, Wong D, Lu S, Dickstein S, Silva M, et al. (2005) Optimal use of fresh and frozen-thawed testicular sperm for intracytoplasmic sperm injection in azoospermic patients. J Assist Reprod Genet 22(11-12): 389-394.

21. Kemi AI, Olukoya OY, Okeke CC, Ogbeche RO, Iloabachie EC, et al. (2013) The use of ultrasound guided transvaginal probe on the anterior abdominal wall for follicular aspiration in a patient with inaccessible ovaries by transvaginal ultrasound. Nigerian quarterly journal of hospital medicine. 23(2): 139-141.

22. Kuang Y, Chen Q Hong Q, Lyu Q Ai A, et al. (2014) Double stimulations during the follicular and luteal phases of poor responders in IVF/ICSI programmes (Shanghai protocol). Reproductive biomedicine online 29(6): 684-691.

ISSN: 2574-1241

DOI: 10.26717/BJSTR.2019.20.003464

Murid Javed. Biomed J Sci \& Tech Res

(C) This work is licensed under Creative Commons Attribution 4.0 License

Submission Link: https://biomedres.us/submit-manuscript.php
23. Wang A, Murugappan G, Kort J, Westphal L (2019) Hormone replacement versus natural frozen embryo transfer for euploid embryos. Arch Gynecol Obstet p. 1-8.

24. Tammiste T, Kask K, Padrik P, Idla K, Rosenstein K, et al. (2019) A case report and follow-up of the first live birth after heterotopic transplantation of cryopreserved ovarian tissue in Eastern Europe. BMC women's health 19(1): 65.

25. Telfer EE (2019) Future developments: In vitro growth (IVG) of human ovarian follicles. Acta obstetricia et gynecologica Scandinavica. 98(5): 653-658.

$\begin{array}{ll}\text { BIOMEDICAL } & \text { Assets of Publishing with us } \\ \text { RESEARCHES } & \text { - Global archiving of articles } \\ & \text { - Immediate, unrestricted online access } \\ & \text { - Rigorous Peer Review Process } \\ \end{array}$

